\title{
Changes of Physico-Chemical Properties of Pig Slurry During Storage
}

\author{
Mansyur ${ }^{\mathrm{a}, \mathrm{b}}$, * \& Hong L. Choi ${ }^{\mathrm{a}}$ \\ aDepartment of Agriculture Biotechnology and Research Institute of Agriculture and Life Science, \\ Seoul National University, Gwanak-ku Seoul 151-921, Republic of Korea \\ bFaculty of Animal Husbandry, University of Padjadjaran, \\ Jln. Raya Bandung - Sumedang, Km 21 Jatinangor, Sumedang, Indonesia \\ (Received 08-12-2010; accepted 30-09-2011)
}

\begin{abstract}
ABSTRAK
Tujuan penelitian ini untuk mempelajari perubahan sifat limbah cair kotoran babi sebagai pupuk organik pada berbagai waktu penyimpanan. Rancangan acak lengkap digunakan pada penelitian ini. Perlakuan yang diberikan adalah waktu penyimpanan, yaitu 0, 15, 30, 45, dan 60 hari. Peubah yang diamati meliputi kehilangan limbah cair, derajat keasaman $(\mathrm{pH})$, konduktivitas elektrik (electrical conductivity, EC), kandungan bahan kering (total solid, TS), bahan kering teruapkan (volatile solid, VS), kandungan total chemical oxygen demand total (tCOD), kandungan soluble chemical oxygen demand total (sCOD), kandungan nitrogen total (total nitrogen, TN), kandungan ammonianitrogen $\left(\mathrm{NH}_{3}-\mathrm{N}\right)$, kandungan nitrat-nitrogen $\left(\mathrm{NO}_{3}-\mathrm{N}\right)$, Kandungan fosfat total (total phosphate, TP), dan kandungan fosfat terlarut (dissolve reactive phosphate, DRP). Hasil penelitian menunjukkan bahwa waktu penyimpanan berpengaruh nyata terhadap seluruh peubah yang diamati, kecuali terhadap kandungan nitrat-nitrogen dan kandungan fosfat total. Derajat keasaman, TS, VS, DRP, dan kehilangan limbah cair meningkat selama penyimpanan, sedangkan $\mathrm{EC}, \mathrm{TN}, \mathrm{NH}_{3}-\mathrm{N}, \mathrm{tCOD}$, dan SCOD mengalami penurunan selama penyimpanan. Sifat fisik dan kimia limbah cair kotoran babi mengalami perubahan selama penyimpanan sebagai hasil perombakan bahan organik yang dikandungnya.
\end{abstract}

Kata kunci: sifat fisik dan kimia, limbah cair, waktu penyimpanan

\section{ABSTRACT}

This study was aimed to determine changes of the characteristics of raw pig slurry as liquid organic fertilizer at various storage times. A completely randomized design was used in this research. The treatments were storage times, i.e.: $0,15,30,45$, and 60 days. Variables observed were loss of the slurry, degree of acidity ( $\mathrm{pH})$, electrical conductivity (EC), total solid (TS), volatile solid (VS), total chemical oxygen demand (tCOD), soluble chemical oxygen demand (sCOD), total nitrogen (TN), ammonia-nitrogen $\left(\mathrm{NH}_{3}-\mathrm{N}\right)$, nitrate-nitrogen $\left(\mathrm{NO}_{3}-\mathrm{N}\right)$, total phosphate (TP), and dissolve reactive phosphate (DRP). The results showed that storage time significantly affected all the observed variables, except the concentration of $\mathrm{NO}_{3}-\mathrm{N}$ and total phosphate content. The pH, TS, VS, DRP, and losses of slurry lost during storage times increased, while $\mathrm{EC}, \mathrm{TN}, \mathrm{NH}_{3}-\mathrm{N}, \mathrm{tCOD}$, and sCOD decreased. Physico-chemical properties of slurry during storage times changed, as a result of organic matter breakdown.

Key words: physico-chemical properties, slurry, storage times

\section{INTRODUCTION}

There is no doubt that livestock manure has benefits as a source of organic fertilizer. Slurry is an important source of organic matter, macro and micronutrients,

\footnotetext{
* Corresponding author:

1E-mail: usloo8@snu.ac.kr; ²e-mail: mancuy@yahoo.com
}

and also heavy metals and pathogens (Araji et al., 2001; Baloda et al., 2001; Barker \& Overcash, 2007; Suresh et al., 2009a). Bulluck et al. (2002) measured a greater improvement in physical properties, chemical, and biological soil, and the increased crop production, when applied organic fertilizer compared to chemical fertilizer. The manure is a good nutrient source for crop production. Several studies have shown that utilization of manure in liquid form support plant growth better than solid form 
(Zhang et al., 2006), because liquid form has higher nitrogen availability than in solid form (Sutton et al., 1986).

Liquid manure usually cannot be directly applied to the land, but they must be collected and stored in storage ponds. Application manure as a liquid fertilizer is usually given after harvesting or before planting. The slurry occur microbiological process (Peu et. al., 2006) and mechanical process during storage, which can change physico-chemical characteristics of the liquid manure. Therefore, the objective of this research was to determine the effect of storage times on physico-chemical properties of pig slurry.

\section{MATERIALS AND METHODS}

\section{Materials}

The pig slurry was collected from pig houses of University Farm, Animal Environment and Bioengineering Laboratory, Seoul National University, located in Suwon, South Korea. The slurry from storage tank (tank volume around 20,000 1) was mixed (10 min using electric pump) and then 1601 slurry was collected, and they were divided into 16 containers, each container was filled 101 of slurry, then slurry was stored and kept in aerobic condition for $2 \mathrm{mo}$ at the laboratory. The room temperature ranged from $12-18{ }^{\circ} \mathrm{C}$, with relative humidity ranged between $65 \%-70 \%$.

\section{Sampling and Analysis of Slurry}

The physico-chemical properties were observed for $2 \mathrm{mo}$, and the samples were collected every 15 days. Each period, samples were taken from four containers. The slurry were stirred and followed by sampling. Fifty $\mathrm{ml}$ samples were taken from each container periodically, and samples were kept in temperature of $4{ }^{\circ} \mathrm{C}$ until they were analyzed.

The collected samples were analyzed for loss of slurry, the degree of acidity $(\mathrm{pH})$, electrical conductivity (EC), total solid (TS), volatile solid (VS), total chemical oxygen demand (tCOD), soluble chemical oxygen demand (sCOD), total nitrogen (TN), ammonia nitrogen $\left(\mathrm{NH}_{3}-\mathrm{N}\right)$, nitrate nitrogen $\left(\mathrm{NO}_{3}-\mathrm{N}\right)$, total phosphate $(\mathrm{TP})$, and dissolved reactive phosphate (DRP). The samples were $\mathrm{pH}$ adjusted $(\mathrm{pH}<2)$ either with $\mathrm{H}_{2} \mathrm{SO}_{4}$ for COD, $\mathrm{TN}, \mathrm{NH}_{3}-\mathrm{N}, \mathrm{NO}_{3}-\mathrm{N}, \mathrm{TP}$, and DRP analyzed.

A loss of slurry was measured by a change of volumes. EC and pH were measured using EC214 conductivity meter (Hana Instruments, Ltd., Sarmeola di aarubano, Italy) and $\mathrm{pH}$ meter (Inolab, WTW $\mathrm{GmbH}$, Weilheim, Germany) with a $0.01 \mathrm{pH}$ resolution over the $\mathrm{pH}$ range 0-14. TS, VS, tCOD, sCOD, TN, $\mathrm{NH}_{3}-\mathrm{N}, \mathrm{NO}_{3}-$ $\mathrm{N}, \mathrm{TP}$, and DRP were analyzed per standard method for water and waste water (Eaton et al., 2005). The total solid and volatile solid were analyzed by gravity method. The tCOD, sCOD, TN, $\mathrm{NH}_{3}-\mathrm{N}, \mathrm{NO}_{3}-\mathrm{N}$, TP, and DRP were analyzed using a DR $5000 \mathrm{UV}$-vis Spectrophotometer (Hach Co., Loveland, Colo) per manufacturer's protocol. Reactor Digestion Method was used to observe tCOD, and sCOD. Persulfate Digestion Method was used to observe TN. Salicylate Method was used to observe
$\mathrm{NH}_{3}-\mathrm{N}$. Chromotropic Acid Method was used to observe $\mathrm{NO}_{3}-\mathrm{N}$. Acid Persulfate Digestion Method was used to observe TP. Molybdovanadate Method was used to observe DRP.

\section{Statistical Analysis}

A completely randomized design was used in this research. Microsoft Office Excel 2007 was used to analyze the experimental data. Data were analyzed by variants analysis, and different mean between treatments were analyzed by Duncans multiple range test $(\mathrm{P}<0.05)$. Person product-moment correlation coefficient were calculated by choosing bivariate with two tailed option to show the relationship between the observed variables.

\section{RESULTS AND DISCUSSION}

Losses of slurry were as a result of evaporation. Mean of losses varied from 0-1.38 1 and the rate of losses was $25 \mathrm{ml} /$ day (Table 1). There were increased in losses of slurry to storage times. Mean of losses at each storage times were significantly different. The amount of evaporation was affected by humidity, and temperature. Evaporation did not evaporate only water, but also evaporated some compounds, as result of organic materials degradation of slurry. Losses of slurry had a close correlation and affected the other properties, such as $\mathrm{pH}, \mathrm{EC}, \mathrm{TS}, \mathrm{VS}, \mathrm{tCOD}, \mathrm{sCOD}, \mathrm{TN}, \mathrm{NH}_{3}-\mathrm{N}$, and DRP (Table 2).

The EC values ranged from $17.33-19.47 \mathrm{mS} / \mathrm{m}$. The highest EC at 0 day storage times, and the lowest EC at 45 days storage times. There was a change of EC values of slurry. EC values during storage times decreased (Table 1). The change of EC values showed that there were changes of ion composition in the slurry, because EC described as a result of measurement of ion transfer between the anode and cathode in the solution. EC was normally considered to measure the solubility of salt in the solution (Motsara \& Roy, 2008), its correlation to concentration of dissolved ions in a solution (Provolo \& Martinez-Suller, 2007). The changes of EC values were as a result of organic compounds degradation and or inorganic compounds to simple molecules or ions. Therefore, EC had a very close relationship with the other properties of slurry (Table 2). The EC had a positive correlation with the ammonia nitrogen $\left(\mathrm{NH}_{3}-\right.$ $\mathrm{N})$, TN, specific gravity (SG), TS, VS, fixed solids (FS), and total dissolved solids (TDS) (Suresh et. al., 2009b).

The $\mathrm{pH}$ values ranged from 7.18 to 7.82 . The $\mathrm{pH}$ slurry significantly increased. The $\mathrm{pH}$ increased gradually during storage periods, and moved from neutral to alkali. It was caused by degradation of some intermediate compound and emitted to the atmosphere. The slurry $\mathrm{pH}$ will become more alkaline in aerobic storage system (Fentonet et al., 1983). On the other hand, increasing acidity would be associated with losses of ammonia. In this study, loss of ammonia continued to rise, because $\mathrm{pH}$ of slurry was higher than 7. It is supported by Zhang \& Lau (2007) that ammonia emission will increase dramatically, when $\mathrm{pH}$ value is higher than 7 . Furthermore, there were negative correlation between $\mathrm{pH}$ and $\mathrm{NH}_{3}-\mathrm{N}$ 
concentration of slurry (Table 2). It means that $\mathrm{pH}$ was affected by ammonia emission to atmosphere. When $\mathrm{pH}$ was low, losses of ammonia from slurry can be reduced.

The mean of TS concentration varied from 16.65-20.21 g/l. The mean of VS ranged from 10.66 to $12.99 \mathrm{~g} / \mathrm{l}$. Concentration of TS and VS increased during storage times (Table 1). Increased concentration of TS and VS in slurry was influenced by the loss of water due to evaporation. Although there were degradation of organic matter, but these did not reduce the concentration of TS and VS, because the rate of water loss through evaporation was greater than the rate of degradation of organic material. Beside that, TS concentrations affected and had a correlation to the other properties such as $\mathrm{pH}$, EC, VS, tCOD, sCOD, TN, $\mathrm{NH}_{3}-\mathrm{N}, \mathrm{DRP}$, and losses of slurry (Table 2).

The mean of tCOD ranged from 25.50-29.35 g/l, while the mean of sCOD varied from 12.75 to $18.70 \mathrm{~g} / \mathrm{l}$ (Table 1). There were decreased of tCOD and sCOD during storage periods. Decreasing of tCOD were significantly different at $0-15$ days storage times and 30 to 45 days storage times, while 15 to 30 days and 45 to 60 days were not significant change. The content of soluble COD decreased during increasing storage times. The COD described the organic substrate in the solution. The tCOD and sCOD decreased during storage periods

Table 1. Physico-chemical properties of pig slurry at various storage times

\begin{tabular}{lcccccc}
\hline \multirow{2}{*}{ Observed variables } & \multicolumn{5}{c}{ Storage times (days) } \\
\cline { 2 - 7 } & 0 & 15 & 30 & 45 & 60 & Significant \\
\hline Losses of slurry $(\mathrm{ml})$ & $0.00 \pm 0.00^{\mathrm{e}}$ & $400.06 \pm 0.05^{\mathrm{d}}$ & $874.11 \pm 45.03^{\mathrm{c}}$ & $1101.47 \pm 65.44^{\mathrm{b}}$ & $1389.50 \pm 105.08^{\mathrm{a}}$ & $* *$ \\
$\mathrm{pH}$ & $7.18 \pm 0.01^{\mathrm{d}}$ & $7.58 \pm 0.05^{\mathrm{c}}$ & $7.64 \pm 0.03^{\mathrm{bc}}$ & $7.71 \pm 0.08^{\mathrm{ab}}$ & $7.77 \pm 0.04^{\mathrm{a}}$ & $* *$ \\
$\mathrm{EC}(\mathrm{mS} / \mathrm{m})$ & $19.47 \pm 1.02^{\mathrm{a}}$ & $19.33 \pm 0.21^{\mathrm{ab}}$ & $18.17 \pm 0.11^{\mathrm{bc}}$ & $17.33 \pm 1.00^{\mathrm{c}}$ & $17.83 \pm 0.25^{\mathrm{c}}$ & $* *$ \\
$\mathrm{TS}(\mathrm{g} / \mathrm{l})$ & $16.65 \pm 0.15^{\mathrm{c}}$ & $17.66 \pm 0.12^{\mathrm{c}}$ & $19.07 \pm 0.08^{\mathrm{b}}$ & $20.21 \pm 1.24^{\mathrm{a}}$ & $19.58 \pm 0.13^{\mathrm{ab}}$ & $* *$ \\
$\mathrm{VS}(\mathrm{g} / \mathrm{l})$ & $10.66 \pm 0.12^{\mathrm{b}}$ & $11.04 \pm 0.12^{\mathrm{b}}$ & $11.98 \pm 1.09^{\mathrm{ab}}$ & $12.99 \pm 1.29^{\mathrm{a}}$ & $12.65 \pm 0.13^{\mathrm{a}}$ & $*$ \\
$\mathrm{tCOD}(\mathrm{g} / \mathrm{l})$ & $29.35 \pm 0.15^{\mathrm{a}}$ & $27.85 \pm 0.15^{\mathrm{b}}$ & $28.05 \pm 0.75^{\mathrm{b}}$ & $26.20 \pm 0.20^{\mathrm{c}}$ & $25.50 \pm 1.00^{\mathrm{c}}$ & $* *$ \\
$\mathrm{sCOD}(\mathrm{g} / \mathrm{l})$ & $18.70 \pm 0.10^{\mathrm{a}}$ & $16.65 \pm 0.15^{\mathrm{b}}$ & $15.85 \pm 0.25^{\mathrm{c}}$ & $15.05 \pm 0.35^{\mathrm{d}}$ & $12.75 \pm 0.55^{\mathrm{e}}$ & $* *$ \\
$\mathrm{TN}(\mathrm{g} / \mathrm{l})$ & $3.90 \pm 0.61^{\mathrm{a}}$ & $3.57 \pm 0.34^{\mathrm{a}}$ & $3.20 \pm 0.41^{\mathrm{ab}}$ & $3.23 \pm 0.48^{\mathrm{ab}}$ & $2.60 \pm 0.12^{\mathrm{b}}$ & $*$ \\
$\mathrm{NH}-\mathrm{N}(\mathrm{g} / \mathrm{l})$ & $1.35 \pm 0.05^{\mathrm{a}}$ & $1.25 \pm 0.04^{\mathrm{b}}$ & $1.18 \pm 0.02^{\mathrm{b}}$ & $1.08 \pm 0.05^{\mathrm{c}}$ & $1.09 \pm 0.04^{\mathrm{c}}$ & $* *$ \\
$\mathrm{NO} \mathrm{3}^{-\mathrm{N}}(\mathrm{g} / \mathrm{l})$ & $0.64 \pm 0.30$ & $0.56 \pm 0.02$ & $0.60 \pm 0.09$ & $0.78 \pm 0.05$ & $0.77 \pm 0.04$ & $\mathrm{NS}$ \\
$\mathrm{TP}(\mathrm{g} / \mathrm{l})$ & $0.41 \pm 0.06$ & $0.42 \pm 0.06$ & $0.42 \pm 0.07$ & $0.44 \pm 0.03$ & $0.45 \pm 0.04$ & $\mathrm{NS}$ \\
$\mathrm{DRP}(\mathrm{g} / \mathrm{l})$ & $0.28 \pm 0.03^{\mathrm{b}}$ & $0.28 \pm 0.02^{\mathrm{b}}$ & $0.40 \pm 0.002^{\mathrm{a}}$ & $0.38 \pm 0.003^{\mathrm{a}}$ & $0.37 \pm 0.02^{\mathrm{a}}$ & $* *$ \\
\hline
\end{tabular}

Note: ${ }^{*}=\mathrm{P}<0.05,{ }^{* *}=\mathrm{P}<0.01, \mathrm{NS}=$ non significant. Values with different superscript of the same row are significantly different $(\mathrm{P}<0.05)$.

$\mathrm{EC}=$ electrical conductivity, $\mathrm{TS}=$ total solid, $\mathrm{VS}=$ volatile solid, $\mathrm{tCOD}=$ total chemical oxygen demand, $\mathrm{sCOD}=\mathrm{soluble}$ chemical oxygen demand, $\mathrm{TN}=$ total nitrogen, $\mathrm{NH}_{3}-\mathrm{N}=$ ammonium nitrogen, $\mathrm{NO}_{3}-\mathrm{N}=$ nitrate nitrogen, $\mathrm{TP}=$ total phosphate, $\mathrm{DRP}=$ dissolve reactive phosphate.

Table 2. Pearson correlation between the observed variables

\begin{tabular}{|c|c|c|c|c|c|c|c|c|c|c|c|c|}
\hline & $\mathrm{pH}$ & EC & TS & VS & tCOD & sCOD & $\mathrm{TN}$ & $\mathrm{NO}_{3}-\mathrm{N}$ & $\mathrm{NH}_{3}-\mathrm{N}$ & $\mathrm{TP}$ & DRP & LS \\
\hline $\mathrm{pH}$ & 1.00 & & & & & & & & & & & \\
\hline $\mathrm{EC}$ & -0.47 & 1.00 & & & & & & & & & & \\
\hline TS & $0.74^{* *}$ & $-0.85^{* *}$ & 1.00 & & & & & & & & & \\
\hline VS & 0.51 & $-0.80^{* *}$ & $0.85^{* *}$ & 1.00 & & & & & & & & \\
\hline tCOD & -0.51 & $0.64^{*}$ & $-0.64^{*}$ & $-0.69^{* *}$ & 1.00 & & & & & & & \\
\hline sCOD & $-0.57^{*}$ & $0.69^{* *}$ & $-0.67^{* *}$ & $-0.69^{* *}$ & $0.91^{* *}$ & 1.00 & & & & & & \\
\hline $\mathrm{TN}$ & -0.42 & $0.65^{* *}$ & $-0.60^{*}$ & $-0.73^{* *}$ & $0.63^{*}$ & $0.77^{* *}$ & 1.00 & & & & & \\
\hline $\mathrm{NO}_{3}-\mathrm{N}$ & 0.028 & -0.17 & 0.30 & 0.29 & -0.50 & -0.40 & 0.08 & 1.00 & & & & \\
\hline $\mathrm{NH}_{3}-\mathrm{N}$ & $-0.69 * *$ & $0.75^{* *}$ & $-0.83^{* *}$ & $-0.80^{* *}$ & $0.87^{* *}$ & $0.861^{* *}$ & $0.78^{* *}$ & -0.27 & 1.00 & & & \\
\hline $\mathrm{TP}$ & -0.03 & -0.21 & 0.28 & 0.06 & -0.02 & 0.04 & 0.17 & 0.45 & -0.05 & 1.00 & & \\
\hline DRP & $0.65^{* *}$ & $-0.80^{* *}$ & $0.85^{* *}$ & $0.69^{* *}$ & $-0.53^{*}$ & $-0.65^{* *}$ & $-0.57^{*}$ & 0.20 & $-0.74^{* *}$ & 0.38 & 1.00 & \\
\hline LS & $0.66^{* *}$ & $-0.78^{* *}$ & $0.82^{* *}$ & $0.79^{* *}$ & $-0.88^{* *}$ & $-0.95^{* *}$ & $-0.75^{* *}$ & 0.40 & $-0.93^{* *}$ & 0.13 & $0.81^{* *}$ & 1 \\
\hline
\end{tabular}

Note: ${ }^{*}=\mathrm{P}<0.05, \quad * *=\mathrm{P}<0.01 . \mathrm{EC}=$ electrical conductivity, $\mathrm{TS}=$ total solid, $\mathrm{VS}=$ volatile solid, $\mathrm{tCOD}=$ total chemical oxygen demand, $\mathrm{sCOD}=$ soluble chemical oxygen demand, $\mathrm{TN}=$ total nitrogen, $\mathrm{NH}_{3}-\mathrm{N}=$ ammonium nitrogen, $\mathrm{NO}_{3}-\mathrm{N}=$ nitrate nitrogen, $\mathrm{TP}=$ total phosphate, $\mathrm{DRP}=$ dissolve reactive phosphate, LS= losses of slurry. 
showed there was degradation of COD, or occurred degradation of organic material. At storage periods, there were activity of microorganisms to break down organic matter, and produced some organic compounds, such as ammonia, volatile fatty acids, organic acids, alcohols, phenolics, sulfides, and so forth. The organic matters are found in slurry are carbohydrates, fat, protein, and NPN. Carbohydrates and fats will be released into the atmosphere in gaseous form, while protein and NPN will be degraded to be simple nitrogen molecules, namely $\mathrm{NH}_{3^{\prime}}$ $\mathrm{N}_{2}, \mathrm{~N}_{2} \mathrm{O}, \mathrm{NO}$, and emitted to the atmosphere (Oenema et al., 2007). Furthermore, ammonia is a gas that indirectly affects to the enhanced greenhouse effect through physical and chemical processes in the atmosphere and soil (Seidl, 1999). Changed of sCOD could be used as indicator for other properties, because sCOD have correlation to $\mathrm{pH}, \mathrm{EC}, \mathrm{TS}, \mathrm{VS}, \mathrm{tCOD}, \mathrm{NH}_{3}-\mathrm{N}, \mathrm{DRP}$, and losses of slurry (Table 2).

The concentration of $\mathrm{TN}$ ranged from 2.49 to 3.80 $\mathrm{g} / \mathrm{l}$ (Table 1). The TN concentration during storage periods decreased. The mean concentrations of $\mathrm{TN}$ at 60 days were significantly different compared to 0-15 days storage times. The decrease was due to nitrogen emissions to the atmosphere. These gases were products from decomposition of urine and undigested proteins in slurry.

The concentration of $\mathrm{NH}_{3}-\mathrm{N}$ varied from 1.03 to 1.40 $\mathrm{g} / \mathrm{l}$ (Table 1). It trends to decrease when storage times increased. Decreasing of $\mathrm{NH}_{3}-\mathrm{N}$ concentration indicated losses of nitrogen in the ammonia form, ammonia in the solution will be evaporated easier. It is supported by many studies. Approximately 50\% losses of nitrogen in slurry are ammonia (Harper et al., 2000), the others are $\mathrm{N}_{2}$, and only a small portion are $\mathrm{N}_{2} \mathrm{O}$ (Rotz, 2004). The release of ammonia from the manure is a slow process which governed by factors as ammonia concentration, $\mathrm{pH}$, temperature, air velocity, and emitting surface area (Aarnink \& Verstegen, 2007). The ammonium ion $\left(\mathrm{NH}_{4}\right)$ will be converted to ammonia $\left(\mathrm{NH}_{3}\right)$ when the degree of acidity increased (Karakashev et al., 2008). In addition, emission of $\mathrm{NH}_{3}$ will be higher if there were increased of temperature and ammonium ion concentration, and the wind will accelerate the emission of $\mathrm{NH}_{3}$ into the atmosphere.

The concentration of $\mathrm{NO}_{3}-\mathrm{N}$ ranged from 0.64 to $0.77 \mathrm{~g} / \mathrm{l}$ (Table 1). There were not different of $\mathrm{NO}_{3}-\mathrm{N}$ concentration, it means that $\mathrm{N}-\mathrm{NO}_{3}$ concentrations were not affected by storage times. It indicated that nitrification process is equal to denitrification process. Nitrate is the end product of nitrification process, converse of ammonium to nitrate by bacterial activity. Nitrate can not be directly emitted into the atmosphere, but it must be conversed to $\mathrm{NO}, \mathrm{N}_{2} \mathrm{O}$, and $\mathrm{N}_{2}$ through denitrification process. Moreover, $\mathrm{NO}_{3}-\mathrm{N}$ concentration did not have correlation to other properties (Table 2)

The mean concentration of $\mathrm{TP}$ varied from 0.41 to $0.45 \mathrm{~g} / \mathrm{l}$ (Table 1). There were no different of TP concentration, it means that TP concentrations were not affected by storage times. Losses of phosphates during storage period by evaporation are extremely rare, because losses of phosphates occur more frequently when slurry is applied to land, through the mechanism of run off and leaching. Losses of phosphates when applied as organic fertilizer has been widely studied (Tabbara, 2003; Daverede et al., 2004).

The mean concentration of DRP varied between from 0.28 to $0.40 \mathrm{~g} / \mathrm{l}$ (Table 1 ). The DRP concentration increased during storage times. The concentration of DRP dramatically increased after 15 days, increased almost $100 \mathrm{mg} / \mathrm{l}$. During storage, there was a change of organic matter to be simple organic compounds or inorganic forms (Fontenot et al., 1983). Although total phosphates concentration did not change, but the composition of phosphates changed, namely from organic phosphate to inorganic phosphates through decomposition process by microorganism. In this study, comparison TP concentration to DRP concentration ranged from $66 \%$ to $89 \%$. According to Sharpley and Moyer (2000), pig slurry contains $80 \%-90 \%$ DRP from TP. The increasing of DRP concentration will increase the availability of phosphor for plant nutrient, while phosphor will be the easiest to uptake by plant. If it is applied to agricultural lands in the form of animal slurry has the potential source of pollution on surface waters, leading to eutrophication.

\section{CONCLUSION}

Physico-chemical properties of pig slurry changed during storage. Losses of slurry, $\mathrm{pH}$, TS, VS, and DRP concentration increased, but EC, tCOD, sCOD, TN, and $\mathrm{NH}_{3}-\mathrm{N}$ concentration decreased during storage period, while concentration of $\mathrm{NO}_{3}-\mathrm{N}$ and $\mathrm{TP}$ did not change. Losses of slurry, sCOD and $\mathrm{NH}_{3}-\mathrm{N}$ concentration had a close correlation to other properties, except to $\mathrm{NO}_{3}-\mathrm{N}$, and TP. The pig slurry as a source of liquid organic fertilizer must be treated to minimize nutrient loss and pollution.

\section{REFERENCES}

Aarnink, A. J. A. \& M. W. A. Verstegen. 2007. Nutrition, key factor to reduce environment load from pig production. Livestock Science 109: 194-203. DOI:10.1016/ j.livsci.2007.01.112

Araji, A. A., Z. O. Abdo, \& P. Joyce. 2001. Efficient use of animal manure on cropland: economic analysis. Bioresour. Technol. 79: 179-191.

Baloda, S. B., L. Christensen, \& S. Trajcevska. 2001. Persistence of a Salmonella enteric Serovar Typhimurium DT12 clone in a piggery and in agricultural soil amended with Salmonella-contaminated slurry. Appl. Environ. Microbiol. 67: 2859-2862.

Barker, J. C. \& M. R. Overcash. 2007. Swine waste characterization: a review. Trans. ASABE 50: 651-657.

Bulluck, L. R., M. Brosius, G. K Evanylo, \& J. B. Ristaino. 2002. Organic and synthetic fertility amendments influence soil microbial, physical and chemical properties on organic and conventional farms. Appl. Soil Ecol. 19: 147-160.

Daverede, I. C., A. N. Kravchenko, R. G. Hoeft, E. D. Nafziger, D. G. Bullock, J. J. Warren, \& L. C. Gonzini. 2004. Phosphorus runoff from incorporated and surface-applied liquid swine manure and phosphorus fertilizer. J. Environ. Qual. 33: 1535-1544.

Eaton, D. A, L. S. Clessceri, E. W. Rice, \& A. E. Greenberg. 2005. Standard Methods for The Examination of Water and Wastewater. 21 ${ }^{\text {st }}$ Edition. American Public Health Association- American Water Work Association - Water Environ- 
ment Federation. Port City Press, Baltimore, Maryland.

Fontenot, J. P., L. W. Smith, \& A. L. Sutton. 1983. Alternative utilization of animal wastes. J Anim Sci. 57: 221-233.

Harper, L. A., R. R. Sharpe, \& T. B. Parkin. 2000. Gaseous nitrogen emissions from anaerobic swine lagoons: Ammonia, nitrous oxide, and dinitrogen gas. J. Environ. Qual. 29: 1356-1365.

Karakashev, K., J. E. Schmidt, \& I. Angelidaki. 2008. Innovative process scheme for removal of organic matter, phosphorus and nitrogen from pig manure. Water Research. 42: $4083-4090$

Motsara, M. R. \& R. N. Roy. 2008. Guide to Laboratory Establishment for Plant Nutrients Analysis. FAO Fertilizer and Plant Nutrition Bulletin No. 19. FAO. Rome. 204.

Oenema, O., D. Oudendag, \& G. L. Velthof. 2007. Nutrient losses from manure management in the European Union. Livestock Science 112: 261-272.

Peu, P., H. Brugere, A.M. Pourcher, M. Kerouredan, J. J. Godon, J. P. Delgenes, \& P. Dabert. 2006. Dynamics of a pig slurry microbial community during anaerobic storage and management. Applied and Environmental Microbiology: 3578-3585.

Provolo, G. \& L. Martinez-Suller. 2007. In situ determination of slurry nutrient content by electrical conductivity. Bioresour. Technol. 98: 3235-3242.

Rotz, C.A. 2004. Management to reduce nitrogen losses in animal production. J Anim Sci. 82:E119-137.
Seidl, W. 1999. Intensification of animal husbandry: effects on global warming and soil quality. Animal Research and Development 49: 1-7.

Sharpley, A. N. \& B. Moyer. 2000. Phosphorus forms in manure and compost and their release during simulated rainfall. J. Environ. Qual. 29: 1462-1469.

Suresh, A., H. L. Choi, J. H. Lee, K. Zhu, H. Q. Yao, H. J. Choi, O. K Moon, C. K. Park, \& J. J. Kim. 2009a. Swine slurry characterization and prediction equations for nutrients on South Korean farms. Trans. ASABE 52: 267-273.

Suresh, A., H. L. Choi, D. I. Oh, \& O. K. Moon. 2009b. Prediction of the nutrients value and biochemical characteristics of swine slurry by measurement of EC - Electrical conductivity. Bioresour. Technol. 100: 4683-4689.

Sutton, A. L., D. W. Nelson, D. T. Kelly, \& D. L. Hill. 1986. Comparison of solid vs. liquid dairy manure applications on corn yield and soil composition. J. Environ. Qual. 15:370-375.

Tabbara, H. 2003. Phosphorus loss to runoff water twenty-four hours after application of liquid swine manure or fertilizer. J. Environ. Qual. 32:1044-1052.

Zhang, M., R. Gavlak, A. Mitchell, \& S. Sparrow. 2006. Solid and liquid cattle manure application in a subarctic soil: Bromegrass and oat production and soil properties. Agron. J. 98:1551-1558.

Zhang, W. \& A. Lau. 2007. Reducing ammonia emission from poultry manure composting via struvite formation. J. Chem. Technol. Biotechnol. 82: 598-602. DOI: 10.102/jtcb. 